\title{
Expansion of an ancient lake in the Kathmandu basin of Nepal during the Late Pleistocene evidenced by lacustrine sediment underlying piedmont slope
}

\author{
Kiyoshi Saijo $^{1^{*}}$ and Kazuo Kimura ${ }^{2}$ \\ ${ }^{1}$ Division of Social Studies Education, Miyagi University of Education, Sendai 980-0845, JAPAN \\ ${ }^{2}$ Department of Integrated Arts and Science, Okinawa National College of Technology, Nago City, Okinawa Prefecture, \\ 905-2192, JAPAN \\ * For correspondence, saijo@staff.miyakyo-u.ac.jp
}

\begin{abstract}
We investigated the geomorphology and surface geology of the piedmont slope on the margins of the Kathmandu basin in the Nepal Himalaya in order to establish Late Pleistocene geography and especially the extent of the ancient lake in the basin. The piedmont slope consists of detrital deposits of colluvial or fluvial origin, underlain and interfingered by organic muddy sediments with radiocarbon ages of about 30,000 yr BP. Detritus from the surrounding hillslopes and lacustrine sediments were alternately deposited as the lake level rose at about that time. The ancient lake in the Kathmandu basin thus reached a level of between 1400 and $1440 \mathrm{~m}$ at around 30,000 yr BP, when it covered almost the entire basin. Because the cols on the surrounding divide are higher than this estimated lake level, and because reddish soils and weathered bedrock are observed on these cols, we conclude that overflow from an outlet other than the Bagmati River probably did not occur. Drainage of the ancient lake by the Bagmati River began just after 30,000 yr BP.
\end{abstract}

Key words: Nepal, Kathmandu basin, piedmont slope, lacustrine, lake level change, Late Pleistocene

According to local legend, Kathmandu basin once held a large lake; the god Manjushree cut the gorge at Chobhar with his mighty Sword of Wisdom to release the lake and open the highly fertile Kathmandu basin to human settlement. The geological record tells a similar story. In this paper we present our findings about the maximal extent of Kathmandu Lake in the Late Pleistocene.

The Kathmandu basin, an intradeep (intramontane basin) on the southern slope of the Nepal Himalaya, is filled with a thick sequence of lacustrine sediments deposited during the Pliocene and Pleistocene. Several terrace surfaces formed as the level of the ancient lake fell. Many studies of these basin-fill deposits and geomorphic surfaces have clarified the paleoclimate and sedimentary environment as well as crustal movement in and around the basin (Yoshida and Igarashi 1984, Gautam et al. 2001, Kuwahara et al. 2001, Sakai 2001, H Sakai et al. 2002, Fujii and Sakai 2002, Dill et al. 2003, Paudayal and Ferguson 2004).

Yoshida and Igarashi (1984) identified six terraces in the basin: from highest to lowest, the Pyanggaon, Chapagaon, Boregaon, Gokarna, Thimi, and Patan geomorphic surfaces. The higher surfaces of middle Pleistocene age (Pyanggaon, Chapagaon, and Boregaon) are distributed only in the southern part of the basin, whereas the Gokarna, Thimi, and Patan surfaces, which formed during the last glacial period, occupy the more northerly part of the basin. Yoshida and Igarashi attributed this distribution to a northward shift of the lake caused by uplift of the southern part of the basin.
In contrast, T Sakai et al. (2002) explained the distribution of geomorphic surfaces in terms of a difference in the sedimentary environments of the northern and southern parts of the basin at the time of maximum lake level. They suggested that the higher geomorphic surfaces in the southern basin had been caused, not by crustal movement, but by the disparities in the catchment area and geomorphic conditions. These divergent explanations for geomorphic developments in the Kathmandu basin require further investigation.

In order to elucidate the paleogeography of the Kathmandu basin, particularly the date at which the ancient lake reached a maximal extent and when it began to drain, we have undertaken a geomorphological investigation of the margins of the basin, where evidence for the lake's extent is most likely to be found. We focus on the characteristics, distribution, and interrelationship of the piedmont slope and the lacustrine sediments.

\section{Study area and characteristics of the piedmont slope}

The floor of the Kathmandu basin, currently between 1250 and $1400 \mathrm{~m}$, is surrounded by ridges of approximately

Himalayan Journal of Sciences 4(6): 41-48, 2007 Available online at www.himjsci.com Copyright $@ 2007$ by Himalayan Association for the Advancement of Science 


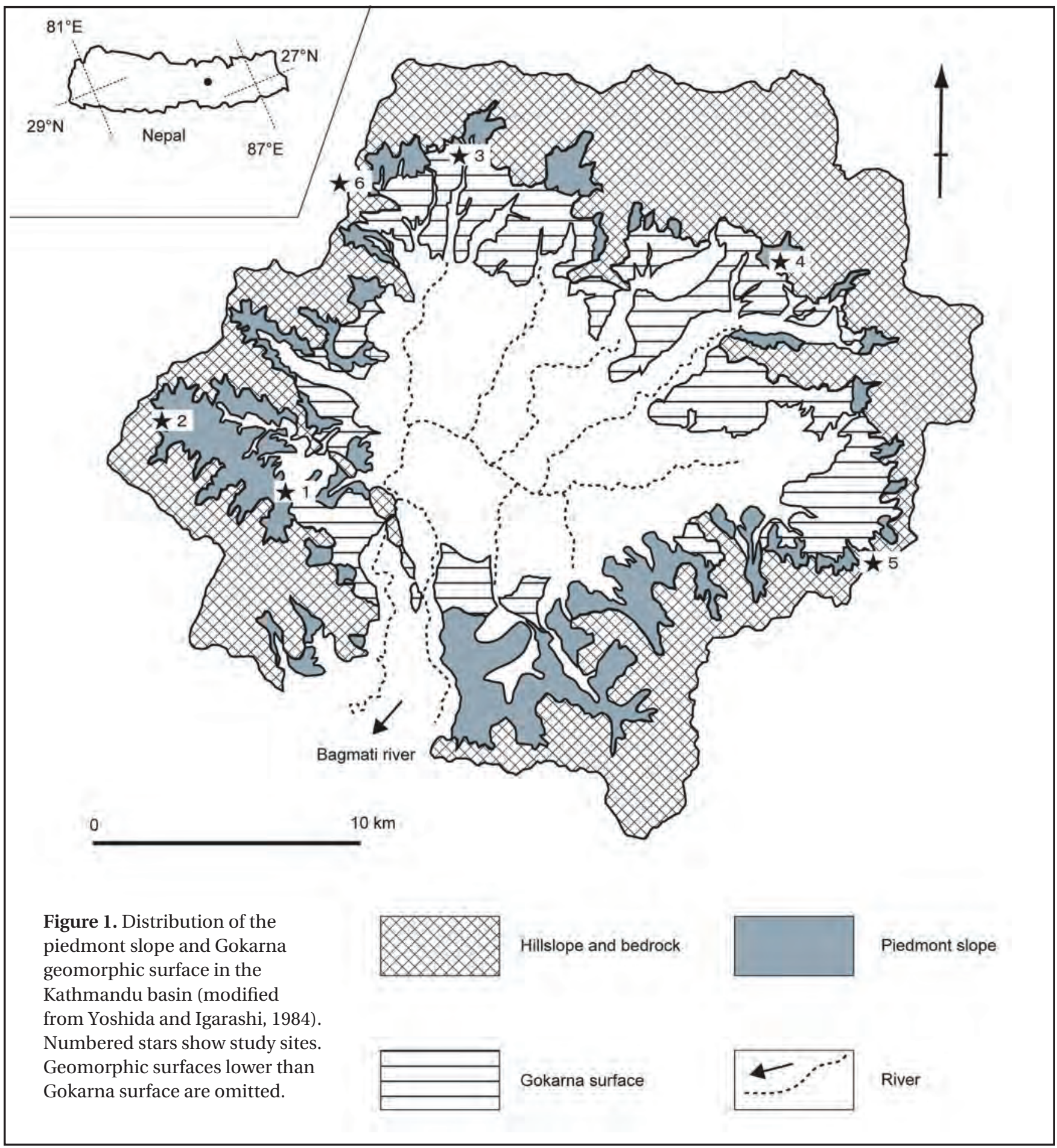

$2000 \mathrm{~m}$ in elevation. At present, the basin is drained by the Bagmati River.

The piedmont slope is well developed where the basin floor meets the surrounding hillslope (Figures 1 and 2). This slope, mostly extending to elevations greater than 1400 $\mathrm{m}$, has a smooth surface with a slightly concave or almost linear longitudinal profile that dips $7^{\circ}$ to $15^{\circ}$ basinward.
In many places, it transitions basinward into the Gokarna surface and fades into narrow valleys in the back slopes. This slope corresponds to the alluvial and talus cones of Yoshida and Igarashi (1984), the colluvial slope of Saijo (1991), and the alluvial cones of Sakai et al. (2001). Based on aerial photo interpretation and analysis of the consistent geomorphological and altitudinal characteristics, we regard 
the three higher terraces in the southern part of the basin as part of the piedmont slope. Saijo (1991) showed that the "colluvial slope" (which we refer to as the "piedmont slope" in this paper) is the result of frequent landslides and debris flows as the climate warmed and became more humid after ca. 25,000 yr BP.

\section{Stratigraphy of the piedmont slope}

We observed the materials composing the piedmont slope at several locations. If the sediments contained organic matter, they were dated by conventional radiometric methods at Beta Analytic Radiocarbon Dating Laboratory, Miami, Florida, USA. The characteristics of the sediments are as follows:

\section{Loc. 1 (1430 m)}

Location 1 is in a gully that dissects the piedmont slope in the southwestern part of the basin. A poorly sorted gravel layer, alternating beds of organic mud and sand, and a gravelly layer, in descending order, are exposed in the sidewall of the gully (Figures 3 and 4). On the basis of its sedimentary facies, we conclude that the uppermost layer, composed mainly of cobble- to boulder-sized subangular and subrounded gravel with a silty matrix, is a debris flow deposit. The underlying unit consists of three conspicuous organic mud layers that interfinger sand layers containing abundant pebble- to cobble-sized gravel, sometimes in lenticular beds, and a little inorganic clay. These sedimentary features indicate that the depositional environment repeatedly changed between swamp and river channel, with occasional small debris flows. Radiocarbon ages obtained from the three organic mud layers are 29,190 $\pm 500 \mathrm{yr}$ BP (Beta-135432), >36,940 yr BP (Beta-135433), and 37,130 \pm 340 yr BP (Beta-135434), in descending order (Figure 4). The lowest layer is an unsorted and unbedded gravelly deposit. Most of the gravel is pebbleto cobble-sized and deeply weathered. We interpret this layer, like the uppermost, to be a debris flow deposit.

\section{Loc. 2 (1460 m)}

Location 2 is in another gully dissecting the piedmont slope in the southwestern part of the basin. We found, from top to bottom, a poorly sorted gravelly deposit containing silty layers in several horizons, a clayey layer accompanied by gravel and sand, and a silty layer (Figure 4). The upper gravelly deposit is composed of cobble- to boulder-sized subangular gravel in a silty matrix. These characteristics suggest that this deposit is of debris flow origin. Although the clayey layer beneath the gravelly deposit is composed mostly of grayish white or brownish gray clay, an organic mud ca. $10 \mathrm{~cm}$ thick and dating to $32,160 \pm 200 \mathrm{yr}$ BP (Beta-140257) is intercalated in the middle part of the layer. This organic mud is interpreted to have been deposited under swampy conditions. The base of the overlying gravelly deposit is clearly defined, and undulating in places, suggesting an unconformable relationship between these two units.

\section{Loc. 3 (1420 m)}

Location 3 is on the piedmont slope in the northernmost part of the basin. Two organic mud layers, which also contain

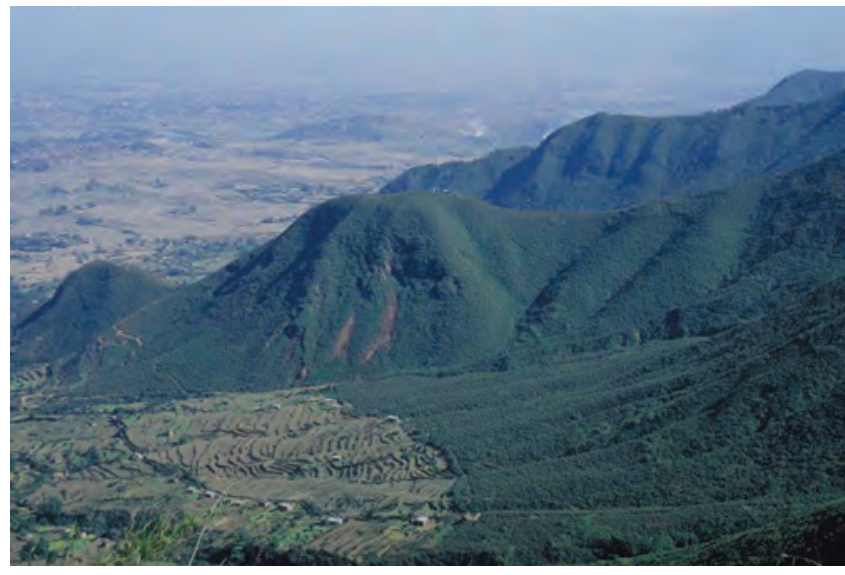

Figure 2. A view of the piedmont slope near Loc. 1. The smooth slope gently dipping northward (left side) and partly cultivated is a piedmont slope

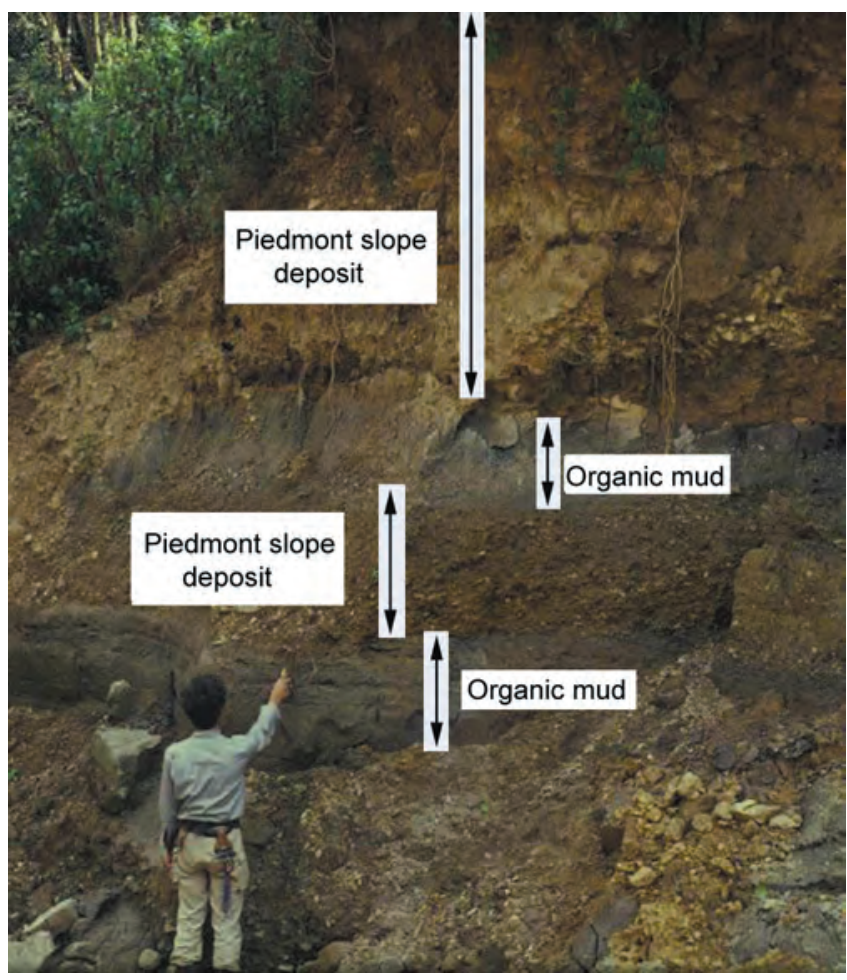

Figure 3. Piedmont slope deposits and organic mud near Loc. 1

abundant inorganic matter, alternate with sandy or clayey layers and are overlain by a sandy bed (Figures 4 and 5). The surficial sandy bed is partly stratified and composed of grayish white coarse sand and scattered angular granule- to pebble-sized gravel. On the basis of their sedimentary facies, we conclude that the two organic mud layers alternating with sandy or clayey layers were deposited in a swamp into which a small river channel occasionally flowed and the surficial sandy bed is a fluvial deposit. The top horizons of the two organic mud layers yielded radiocarbon ages of 37,100 \pm 1150 yr BP (Beta-140259) and >40,300 yr BP (Beta-140260). 


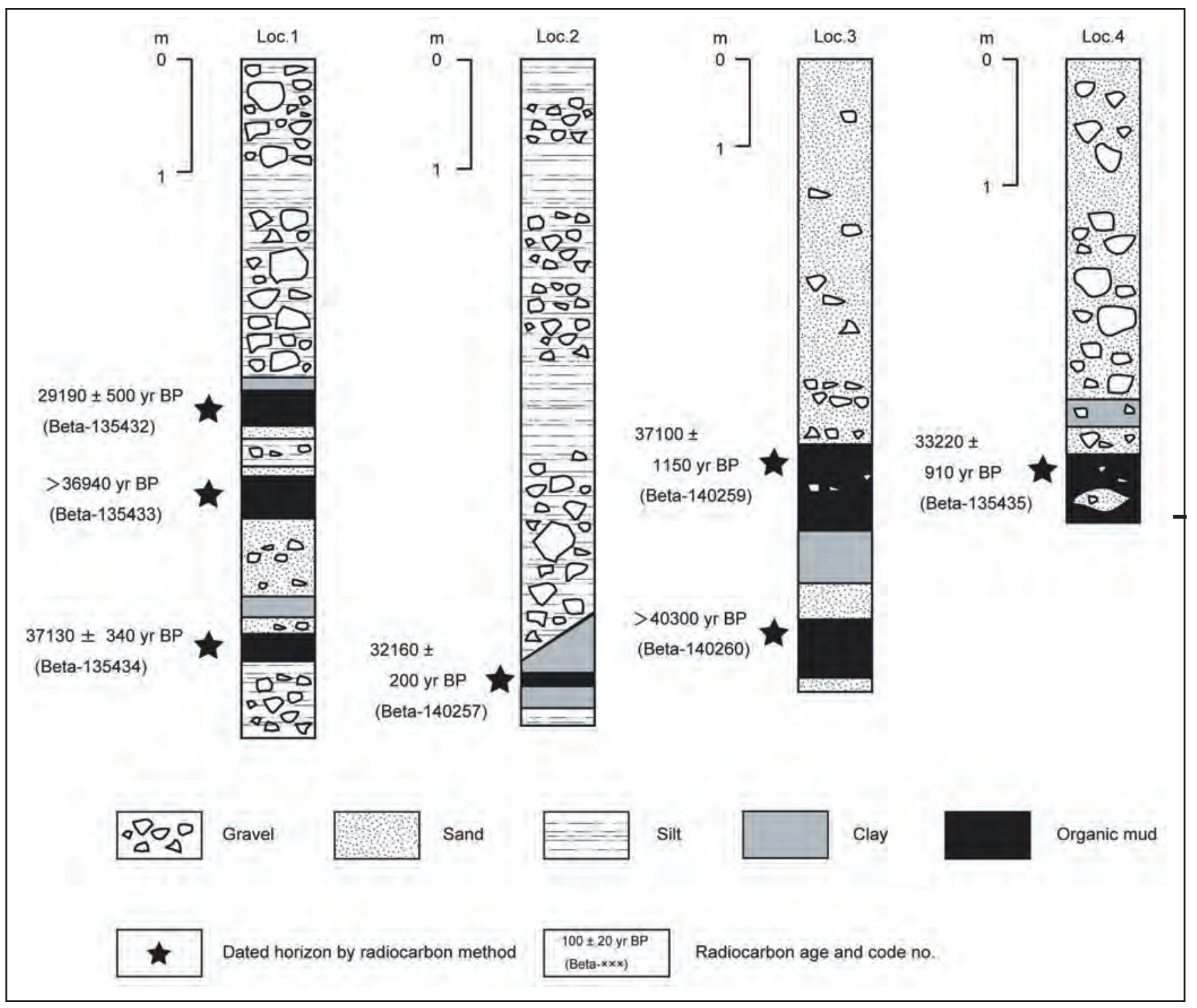

Figure 4. Stratigraphic sections of Locs. 1-4

\section{Loc. 4 (1435 m)}

Location 4 is on the piedmont slope in the northeastern part of the basin. A gravelly deposit, clay and sand beds with pebble-sized gravel, and an organic mud layer, in descending order, are exposed (Figure 4). The upper gravelly deposit is composed of subangular and subrounded gravel within a sandy matrix. The organic mud layer contains abundant sand and granule- to pebble-sized gravel, sometimes in lenticular beds. The sedimentary facies shows that this organic mud layer is a swampy sediment and the overlying clastic sediments are of debris flow origin. The uppermost part of the organic mud was dated at 33,220 $\pm 910 \mathrm{yr}$ BP (Beta-135435).

At all these sites (Locs. 1-4), the uppermost parts of the piedmont slope are composed of poorly sorted gravel or sandy layers with gravel. Both their facies and their geomorphological settings indicate that these sediments (hereafter, piedmont slope deposits) are colluvial or fluvial deposits derived from the hillslope. The sediments underlying the piedmont slope deposits are organic muds including, or alternating with, clastics. These characteristics suggest that the sediments were deposited in a swampy environment where inflow of colluvial or fluvial sediments occurred frequently.

\section{Elevations and topsoils of low cols on the surrounding divide}

All of the contemporary rivers in the Kathmandu basin belong to the Bagmati River system. The surrounding ridges, which divide the Bagmati River catchment from the Kosi River catchment to the east and the Trisuri River catchment to the west, have some relatively low cols. Because, as 
discussed below, we found that the level of the ancient lake in the basin was above $1400 \mathrm{~m}$ at around 30,000 $\mathrm{yr}$ BP and that the lake water covered almost the entire basin, we believe it is likely that the ancient lake was drained at that time not by the Bagmati River but by another river. To investigate this possibility, we surveyed the elevations of two of the low cols and examined their topsoils.

\section{Loc. 5 (1520 m)}

The lowest col between the Bagmati River catchment and the Kosi River catchment, elevation ca. 1520 m, is near the village of Saga (Loc. 5). Red soil and weathered bedrock are found on the western (Kathmandu basin side) slope of this col down to $1440 \mathrm{~m}$, whereas organic muddy sediments, which we regard as lacustrine sediments deposited in the ancient lake in the Kathmandu basin, are distributed below $1430 \mathrm{~m}$ (Figure 6). We interpret the red soil and weathered bedrock as the product of long-term weathering under warm and humid climatic conditions, and their presence at a given site suggests that the site was not submerged (at least not during the Late Pleistocene). Thus, the Saga col and its western slope above $1440 \mathrm{~m}$ have not been submerged throughout the Late Pleistocene.

\section{Loc. 6 (1465 m)}

The lowest col between the Bagmati and the Trisuli River catchments, which is also the lowest col anywhere on the divide, is the Tinpiple col (Loc. 6), at an elevation of ca. 1465 m. Organic muddy sediments, which we regard as lacustrine sediments deposited in the ancient lake, can be recognized up to $1400 \mathrm{~m}$ on the Kathmandu basin side of this col, and red soil and weathered bedrock are exposed at Loc. 6 (Figure 7 ), suggesting that this site has not been submerged since the Late Pleistocene.

\section{Discussion}

Because organic muddy sediments underlie or interfinger with the piedmont slope deposits, it is evident that swampy conditions existed at both the northern and southern margins of the Kathmandu basin around 30,000 yr BP. There are two ways in which a swamp environment might have formed. One is that swamps were formed at the hillfoot independent of the ancient lake in the Kathmandu basin. In that case, the water level of the swamps would have had no relation to the level of the lake. Alternatively, the swamps may have been part of the shoreline of the lake in the basin, which means that the shoreline had expanded to approach the base of the surrounding mountains.

We consider that the formation of local swamps independently of the lake in the Kathmandu basin is improbable for the following reasons. First, it is not easy to explain the appearance of local swamps, which would require a small depression at all four sites identified as Loc. 1, Loc. 2, Loc.3, and Loc. 4. At Loc. 1 and 2, small depressions might have formed in relation to activity of the Chandragiri fault (Saijo et al. 1995) or the Thankot fault (Asahi 2003), which pass near these locations with NW-SE strike. However, no geomorphological settings likely to produce small depressions, such as active faults

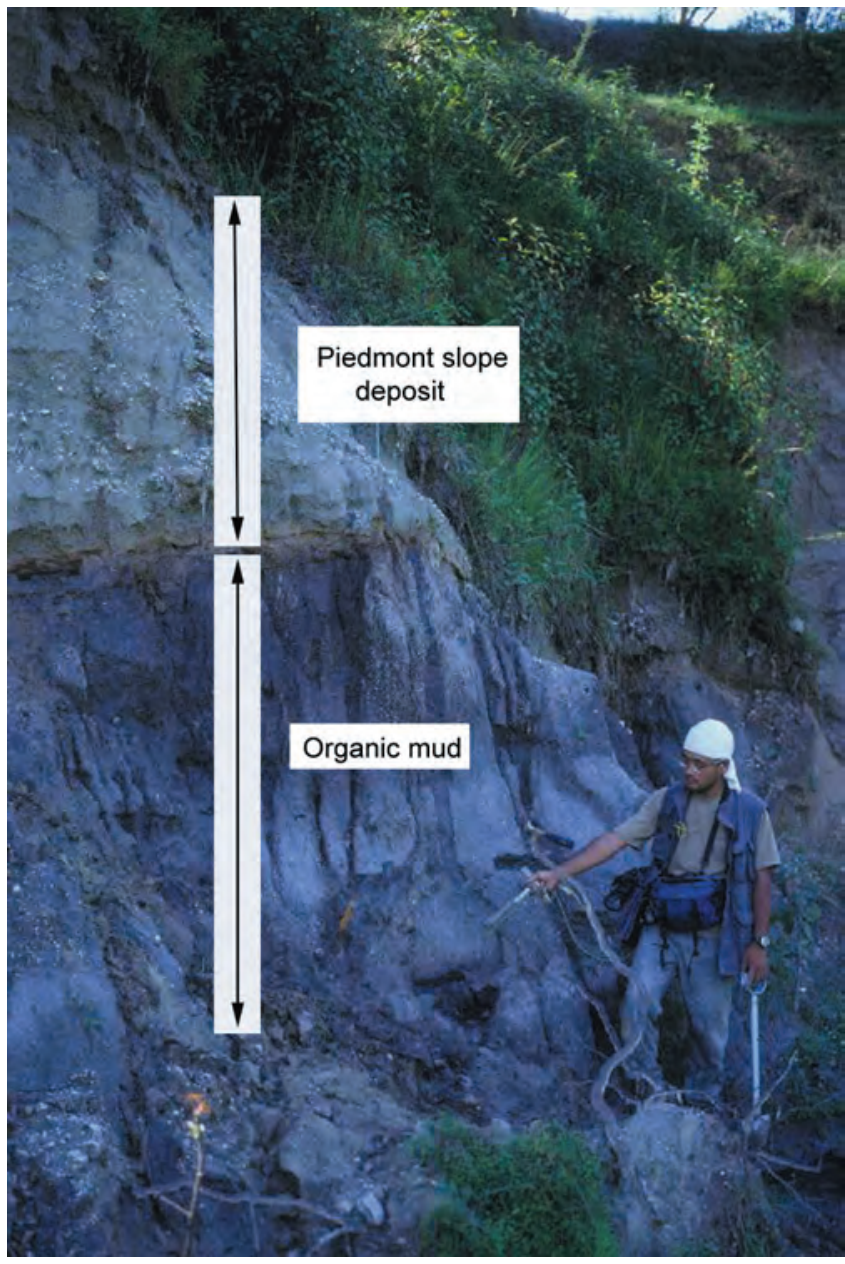

Figure 5. Piedmont slope deposits and organic mud at Loc. 3

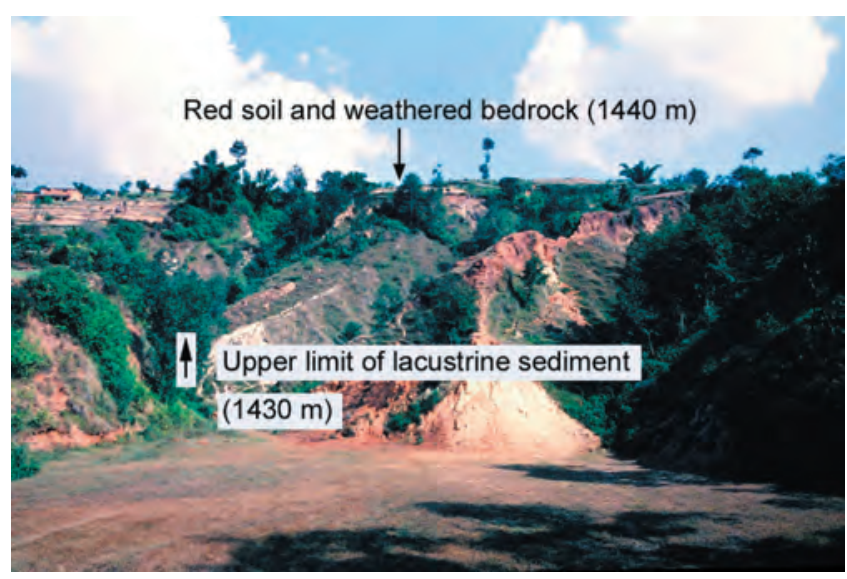

Figure 6. Distribution of lacustrine sediments and red soil and weathered bedrock near Loc. 5

or landslides, are recognized near Loc. 3 and 4. Further, the depositional ages of the organic muddy sediments of Loc. 1 to 4 are almost identical. If each of them had been deposited in a different swamp, then their similarity in age would be difficult to explain. The hypothesis that the organic 


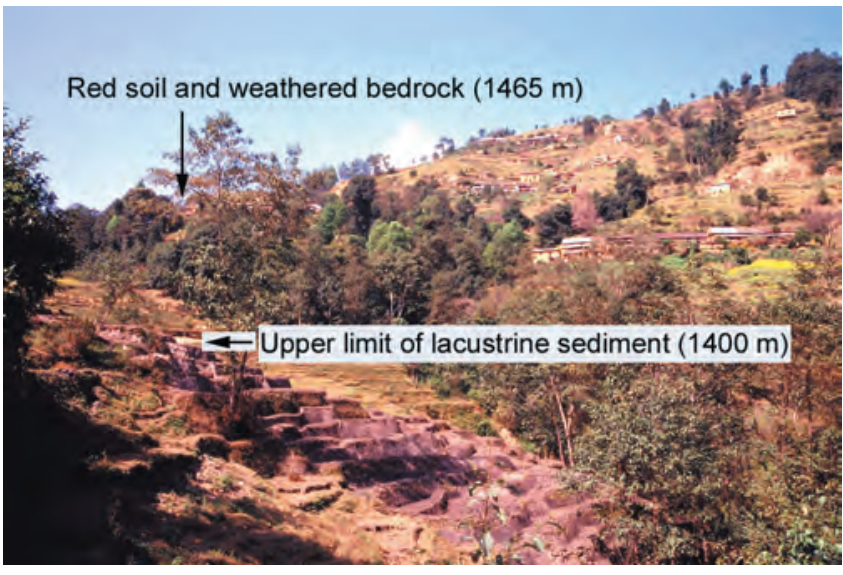

Figure 7. Distribution of lacustrine sediments and red soil and weathered bedrock near Loc. 6

muddy sediments were deposited on the margin of the lake in the basin does not raise the same questions, and is thus plausible. Therefore, we regard the organic mud underlying the piedmont slope deposits as sediments laid down near the shoreline of the ancient lake in the Kathmandu basin. Figure 8 shows our interpretation of a sedimentary environment in which deposition alternated between organic sediments and detritus as the lake level rose in the foothills. Radiocarbon dates obtained from the uppermost organic sediments indicate that they were deposited at around 30,000 yr BP, suggesting that the shoreline of the ancient lake at that time approached the base of the surrounding mountains, and that lake water occupied almost the entire basin (Figure 9).

We know from the elevations of the described locations that the water level of the ancient lake was certainly above $1400 \mathrm{~m}$ at around 30,000 yr BP. At Loc. 5, however, the lake level apparently did not exceed $1440 \mathrm{~m}$, whereas the elevation of Loc. 2 is obviously higher than $1440 \mathrm{~m}$. This discrepancy can be explained by the fact that Loc. 2 is on the hanging wall of the active Chandragiri fault. The rate of vertical displacement of this fault is estimated to be 1.0 $\mathrm{mm} / \mathrm{yr}$ (Saijo et al. 1995). Therefore, the ground surface near Loc. 2 may have been uplifted $30 \mathrm{~m}$ or so during the past 30,000 years, suggesting that the original elevation of Loc. 2 might have been ca. $1430 \mathrm{~m}$. Although the lake level about 30,000 yr BP cannot be determined precisely, we presume that it was at $1420 \mathrm{~m}$ or higher.

If tectonic movement is discounted, the elevations of the low cols were higher than the estimated lake level. In addition, the red soil and weathered bedrock observed on the cols indicate that they have not been covered by lake water and, therefore, that the lake water did not overflow the cols. Even though the ancient lake persisted until 10,000 yr BP (Sakai 2001), drainage of the lake by the Bagmati River began just after 30,000 yr BP. The Gokarna surface emerged as the lake drained. Debris continued to be supplied from the surrounding mountains even after recession of the lake, resulting in the formation of the piedmont slope.

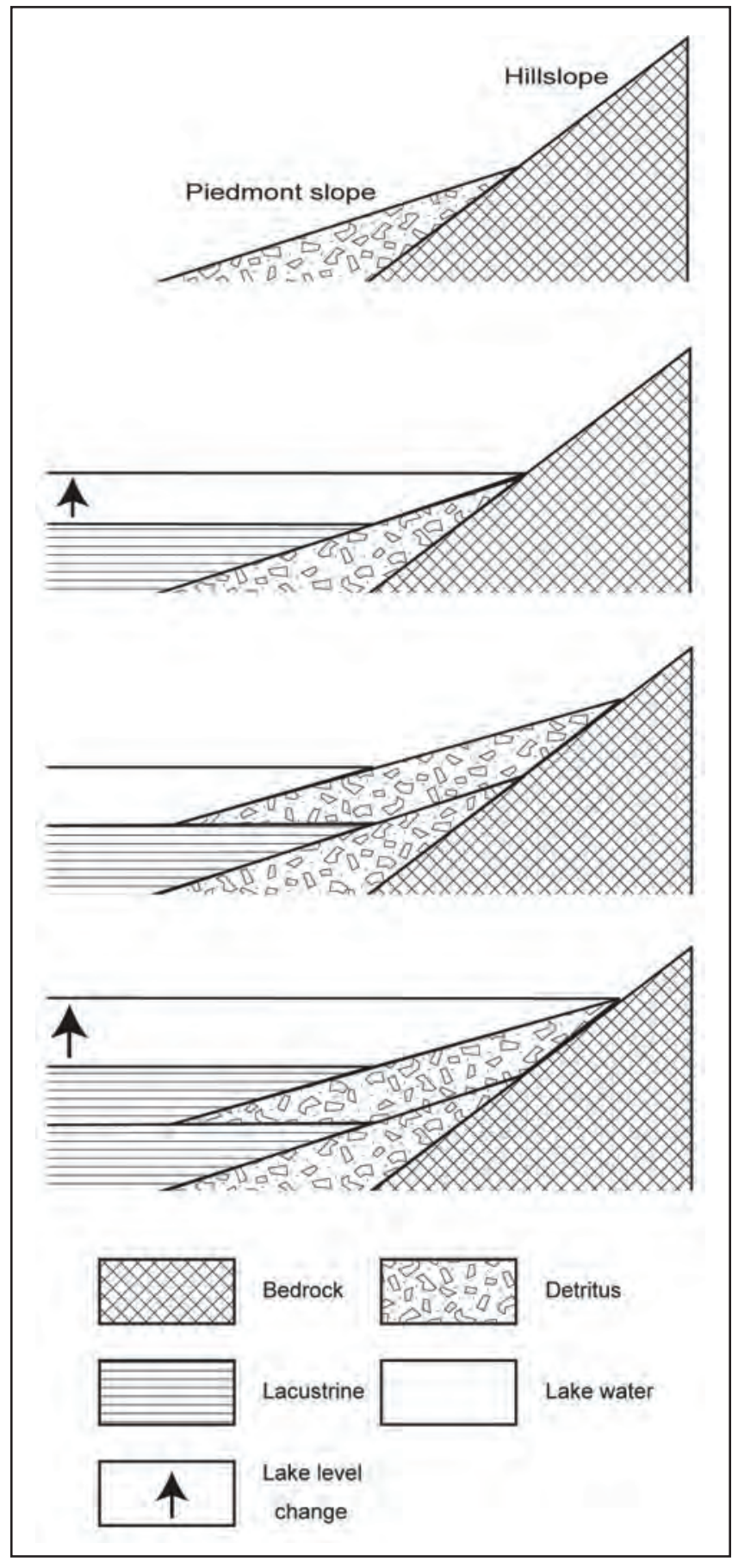

Figure 8. Schematic diagram showing development of interfinger of piedmont slope deposits and lacustrine sediments as lake level rose (chronologically, from top to bottom)

\section{Conclusions}

We undertook a geomorphic survey of the marginal area of the Kathmandu basin to investigate its paleogeography and landform development in relation to lake level change during the Late Pleistocene. The major results are as follows: 


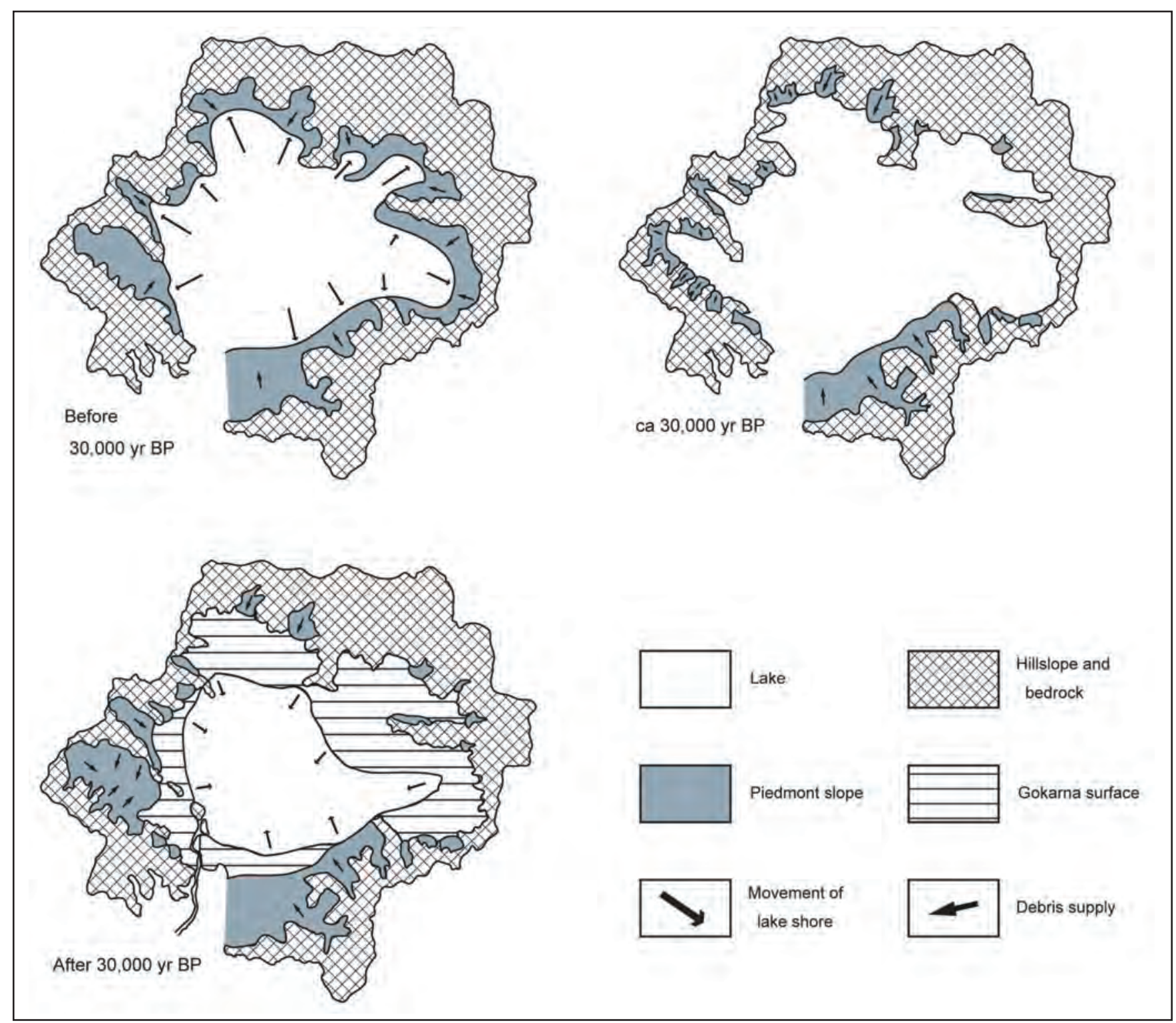

Figure 9. Paleogeography of the Kathmandu basin around 30,000 yr BP

1. The piedmont slope is well developed at the foot of the mountains surrounding the Kathmandu basin. This slope, which dips basinward at about $10^{\circ}$, has a smooth surface and a slightly concave to almost linear longitudinal profile. It transitions basinward into the Gokarna surface and fades into narrow valleys in the back slopes.

2. The surficial deposits (mostly several meters thick) of the piedmont slope are composed of detritus of colluvial or fluvial origin, and organic muddy sediments underlie or interfinger with the detrital deposits. The detrital deposits from hillslope (piedmont slope deposits) are inferred to have been deposited near the shoreline of the ancient lake in the Kathmandu basin, alternating with lacustrine sediments as the lake level rose.
3. The organic muddy sediments under the piedmont slope deposits yield radiocarbon ages mostly around 30,000 yr BP. This fact, along with the sedimentary environment, suggests that the ancient lake covered almost all of the Kathmandu basin at that time. We estimate that the water level of this huge lake was then between 1400 and $1440 \mathrm{~m}$.

4. Elevations of the cols on the surrounding divide are higher than the estimated highest level of the expanded ancient lake. In addition, we observed reddish soils and weathered bedrock on these cols, suggesting that they were never covered by lake water and, therefore, that the lake did not drain through an outlet other than the Bagmati River.

5. Drainage of the ancient lake by the Bagmati River began 
just after 30,000 yr BP. The Gokarna surface emerged as the lake drained. Debris continued to be supplied from the hillslopes even as the lake receded, resulting in the formation of the piedmont slope.

\section{Acknowledgments}

We thank Kazunori Arita and the Japan Society for the Promotion of Science for financial support of this work by Grant-in-Aid for Scientific Research (A) No. 11691112.

\section{References}

Asahi K. 2003. Thankot active fault in the Kathmandu Valley, Nepal Himalaya. Journal of the Nepal Geological Society 28: 1-8

Dill HG, DR Khadka, R Khanal, R Dohrmann, F Melcher and K Busch. 2003. Infilling of the Younger Kathmandu-Banepa intermontane lake basin during the Late Quaternary (Lesser Himalaya, Nepal): a sedimentological study. Journal of Quaternary Science 18(1): $41-60$

Fujii R and H Sakai. 2002. Paleoclimatic changes during the last 2.5 myr recorded in the Kathmandu Basin, Central Nepal Himalayas. Journal of Asian Earth Sciences 20(3): 255-266

Gautam P, A Hosoi, T Sakai and K Arita. 2001. Magnetostratigraphic evidence for the occurrence of pre-Brunhes ( $>780 \mathrm{kyr}$ ) sediments in the northwestern part of the Kathmandu Valley, Nepal. Journal of the Nepal Geological Society 25 (Special Issue): 99-109

Kuwahara Y, R Fujii, H Sakai and Y Masudome. 2001. Measurement of crystallinity and relative amount of clay minerals in the
Kathmandu Basin sediments by decomposition of XRD patterns (profile fitting). Journal of the Nepal Geological Society 25 (Special Issue): 71-80

Paudayal KN and DK Ferguson. 2004. Pleistocene palynology of Nepal. Quaternary International 117: 69-79

Saijo K. 1991. Slope evolution since latest Pleistocene time on the north slope of Chandragiri, Kathmandu valley in the middle mountains of Nepal. Science Reports of Tohoku University, 7th Series (Geography) 41(1): 23-40

Saijo K, K Kimura, G Dongol, T Komatsubara and H Yagi. 1995. Active faults in southwestern Kathmandu Basin, central Nepal. Journal of the Nepal Geological Society 11 (Special Issue): 217-224

Sakai H. 2001. Stratigraphic division and sedimentary facies of the Kathmandu Basin Group, central Nepal. Journal of the Nepal Geological Society 25 (Special Issue): 19-32

Sakai H, R Fujii and Y Kuwahara. 2002. Changes in the depositional system of the Paleo-Kathmandu Lake caused by uplift of the Nepal Lesser Himalayas. Journal of Asian Earth Sciences 20(3): 267-276

Sakai T, AP Gajurel, H Tabata and BN Upreti. 2001. Small-amplitude lake-level fluctuations recorded in aggrading deltaic deposits of the Upper Pleistocene Thimi and Gokarna formations, Kathmandu Valley, Nepal. Journal of the Nepal Geological Society 25 (Special Issue): 43-51

Sakai T, AP Gajurel, N Ooi, H Tabata, T Takagawa and BN Upreti. 2002. Formation of the higher terraces in the Kathmandu basin, Nepal. Chikyu Monthly 24(5): 352-358 (in Japanese)

Yoshida M and Y Igarashi. 1984. Neogene to Quaternary lacustrine sediments in the Kathmandu Valley, Nepal. Journal of the Nepal Geological Society 4 (Special Issue): 73-100 